\title{
CHONDROSARKOMOS JAUTRUMAS SPINDULINEI TERAPIJAI: METASTAZAVUSIOS SPINALINĖS CHONDROSARKOMOS KLINIKINIS ATVEJIS
}

\author{
Aista Plieskienè \\ Klaipédos universitetinè ligoninè
}

Raktažodžiai: chondrosarkoma, spindulinè terapija.

\begin{abstract}
Santrauka
Chondrosarkoma - mezenchiminès kilmès minkštụjų audinių piktybinis navikas. Šio naviko ląstelès gamina hialininę kremzlę. Mitotiškai aktyvios, blogai diferencijuojamos chondrosarkomos (G3) dažnai metastazuoja. Radiobiologijos mokslo duomenimis - chondrogeniniai navikai priskiriami radiorezistentiškiems. Tokiais atvejais spindulinè terapija mažai efektyvi. Straipsnyje aprašomas ị nugaros smegenų kanalą ir minkštuosius bei parenchiminius organus išplitusios pirminès spinalinès chondrosarkomos atvejis, kurio gydymui skirta paliatyvi spindulinè terapija davé gerus naviko ir jo metastazių lokalios kontrolès rezultatus, kai chemoterapija jau nebuvo efektyvi. Straipsnyje aptariama ligos eiga, chondrosarkomos metastazavimo keliai, gydymo išorinès spindulinès terapijos metodu rezultatai ir ypatumai.
\end{abstract}

\section{İvadas}

Chondrosarkomos sudaro heterogenišką navikų grupę, kurių ląstelès produkuoja hialininę kremzlę. Tai trečias pagal dažnị diagnozuojamas kaulų piktybinis navikas po mielomos ir osteosarkomos (1). Pagrindinis chondrosarkomų gydymo metodas - operacinis. Dèl išryškejjusios šio naviko tarpląstelinès terpès, mažo besidalijančių ląstelių skaičiaus ir blogos vaskuliarizacijos, chondrosarkomos yra rezistentiškos chemoterapijai ir spindulinei terapijai. Tačiau tais atvejais, kai pirminis navikas neoperabilus, arba diagnozuojamos metastazès, spindulinè terapija yra pasirinkimo metodas siekiant kontroliuoti ligos simptomus, sustabdyti navikinio proceso progresavimą. Dažniausia siekiama realizuoti $>60$ Gy suminę dozę ị naviką. Tačiau dažnai dozès paskyrimą riboja greta esantys kritiniai organai, ypač neurologinès anatominès struktūros $(1,2)$. Pasitelkiant šiuolaikinès spindulinès terapijos metodus, klinikinejje praktikoje gydant kaulų piktybinius navikus atsivère naujos galimybès ne tik didinti paskirtają suminę spindulinès terapijos dozę, bet ir pakartotinai švitinti recidyvuojančius, nerezektabilius skeleto navikus.

\section{Klinikinis atvejis}

Ligonis $(22 \mathrm{~m}$.) atvyko radioterapeuto konsultacijos i Klaipèdos universitetinę ligoninę $2011 \mathrm{~m}$. lapkričio mènesị dèl progresuojančios krūtininès (VTh 4/5) stuburo dalies chondrosarkomos paliatyvaus spindulinio gydymo. Išplitęs navikinis procesas buvo diagnozuotas $2008 \mathrm{~m}$. Histologinè naviko struktūra atitiko blogai diferencijuotos (G3) mezenchiminès chondrosarkomos vaizdą. Pacientas gydytas sistemine chemoterapija, vèliau operuota pirminè chondrosarkoma ir plaučių metastazès. Alternatyvių sisteminès chemoterapijos galimybių šiam pacientui daugiau nebuvo. $2011 \mathrm{~m}$. liga progresavo metastaze tarpuplautyje, kurios maksimalus diametras sieke $4,5 \mathrm{~cm}$. Pirmuoju etapu pacientui buvo skirta paliatyvi spinduliné terapija (ST) i tarpuplauti, realizuota SD 50 Gy, 25 fr per 5 savaites. Toliau stebint pacientą, $2012 \mathrm{~m}$. vasarą kompiuterinès tomografijos vaizdinime buvo diagnozuotos operabilios dešinès juos-

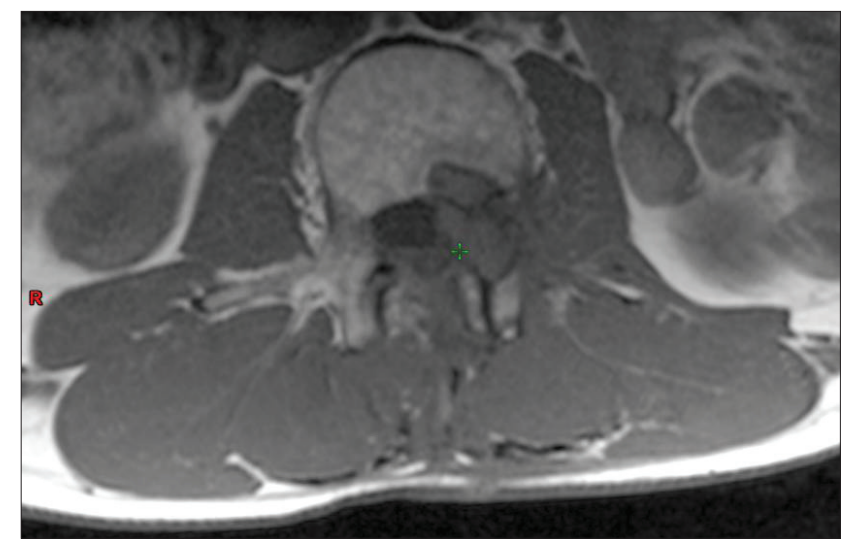

1 pav. Chondrosarkomos metastazių plitimas nugaros smegenų kanale: MRT vaizdinimas 
mens srities minkštujų audinių metastazès, kurios operuotos bei realizuotas antrasis spindulinès terapijos etapas. Per tolimesni paciento stebėsenos laikotarpị šiose anatominėse srityse ligos progresavimo požymių nebuvo nustatyta. 2013 metu pavasari vizualizuotos chondrosarkomos metastazès stuburo kanale, trečiojo liemens slankstelio (VL3) srityje. Pacientas operuotas, atlikta metastazès šalinimo operacija. Po ilgos pertraukos vèl skirta chemoterapija. Po 6 mènesių, kliniškai progresuojant skausminiam sindromui lumbalinèje srityje, magnetinio rezonanso tomogramoje (MRT) vèl vizualizuotas metastazès augimas stuburo kanale ekstraduraliai 2 ir 3 liemens slankstelio (VL2-VL3) lygmenyje, daugiau iš kairès, spaudžiančios nugaros smegenų maišą, dislokuojančios L2, L3 šakneles. Pacientas buvo pakartotinai operuotas skubos tvarka ir 2013 gruodžio mènesi pradèta paliatyvi pooperacinè ST. Realizuota SD $45 \mathrm{~Gy}, 25 \mathrm{fr}$. Lokalios kontrolès rezultatų buvo pasiekta iki $2015 \mathrm{~m}$. sausio, kai MRT vaizdinime diagnozuotas tolimesnis VL2-4 srities metastazių progresavimas. Klaipèdos universitetinèje ligoninèje ryžtasi pacientą pakartotinai operuoti, atlikta subtotali chondrosarkomos metastazès šalinimo operacija pašalinant epiduraliai bei $i$ intervertebrines angas augančias chondrosarkomos metastazes. Siekiant maksimalios klinikinių simptomų ir lokalios kontrolès, toliau nuspręs-
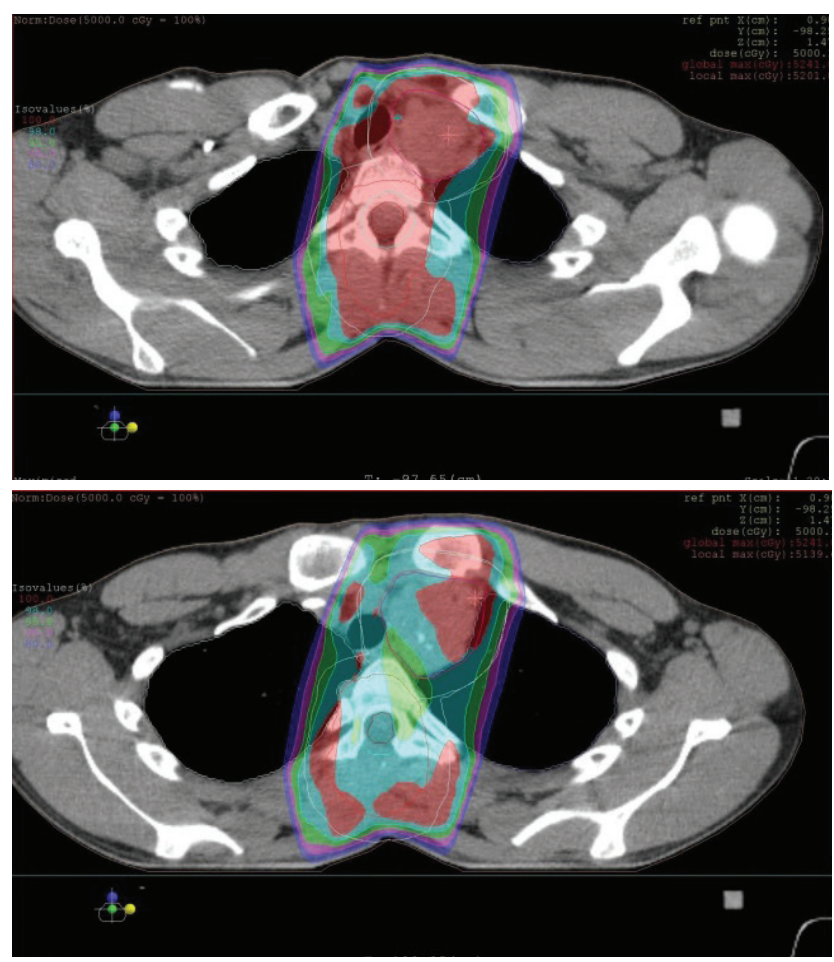

2 pav. Paliatyvi ST ị tarpuplaučio limfmazgių metastazes: realizuota SD 50Gy/25 fr/5 sav.

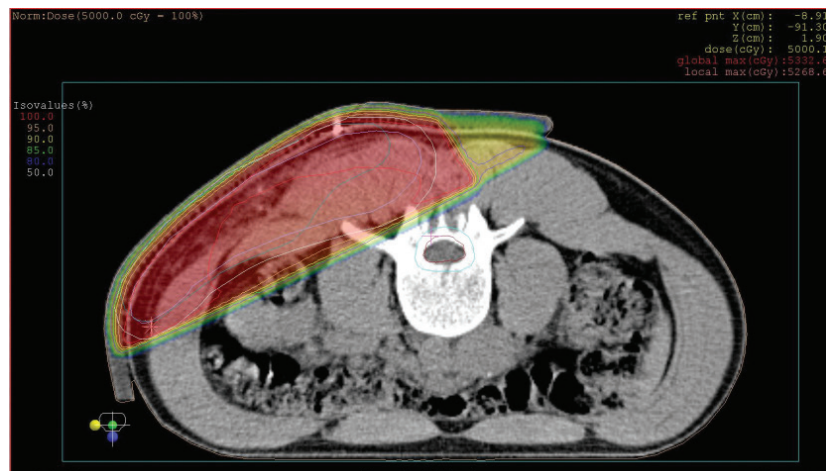

3 pav. Paliatyvi ST i minkštuju juosmens srities audinių metastazių ložę (R1) realizuota SD 56Gy/28 fr/5,5 sav.

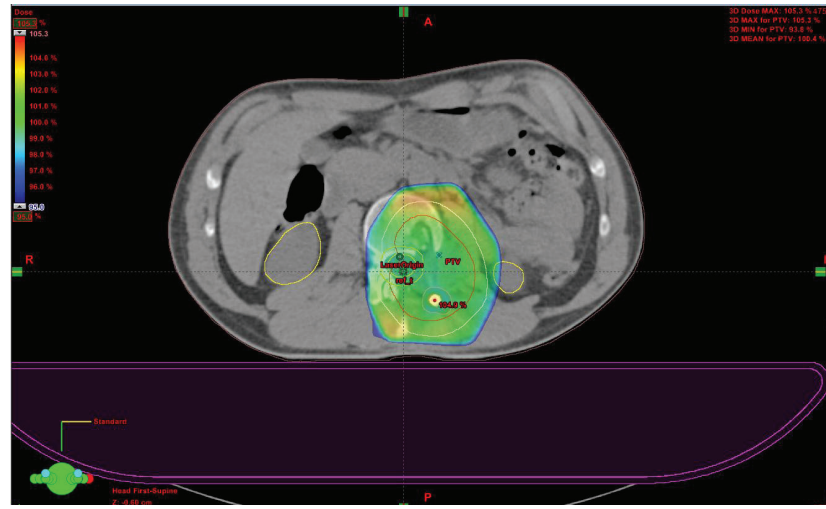

4 pav. Paliatyvi ST i VL2-VL4 metastazes - ị metastazių ložę (R1) realizuota SD $45 \mathrm{~Gy} / 25 \mathrm{fr} / 5 \mathrm{sav}$.

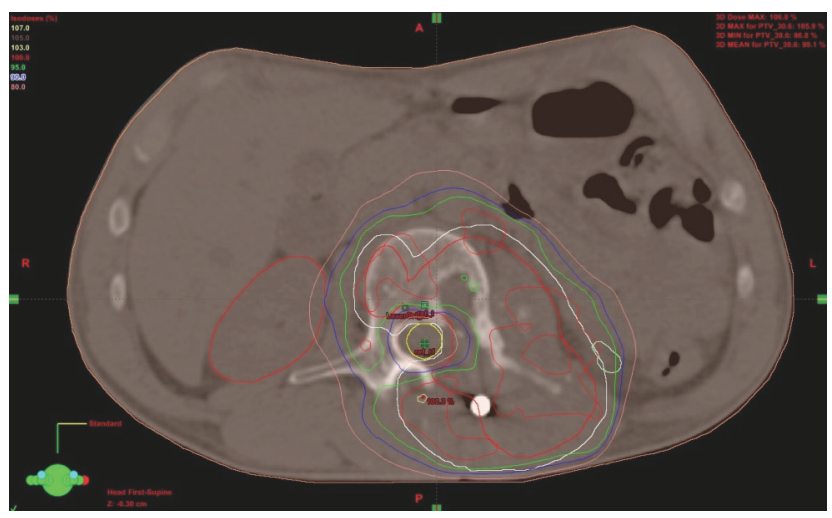

5 pav. Pakartotinè ST ị VL2-VL4 metastazes: realizuota SD 30,6 Gy/17 fr/3,5 sav.

ta skirti pakartotiną paliatyvią ST ị metastazes. Realizuota SD 30,6 Gy, 17 fr, blokuojant nugaros smegenis. Po šio gydymo gautas nuskausminamasis efektas, dalinè mielopatijos simptomų regresija. Pacientas toliau gydomas palia- 
1 lentelè. Spindulinio gydymo etapai, realizuota dozè ir rezultatai

ST-spindulinè terapija

\begin{tabular}{|c|c|c|c|c|}
\hline $\begin{array}{l}\text { Chondrosarkomos metas- } \\
\text { tazių lokalizacija (anato- } \\
\text { minè ligos progresavimo } \\
\text { sritis) }\end{array}$ & $\begin{array}{c}\text { Progresavi- } \\
\text { mo (metas- } \\
\text { tazių) } \\
\text { diagnozès } \\
\text { data } \\
\end{array}$ & $\begin{array}{l}\text { Opera- } \\
\text { cinis gy- } \\
\text { dymas }\end{array}$ & $\begin{array}{l}\text { Realizuota pa- } \\
\text { skirtoji spindu- } \\
\text { linès terapijos } \\
\text { dozė (Gy) }\end{array}$ & $\begin{array}{l}\text { Gydymo } \\
\text { rezultatas }\end{array}$ \\
\hline $\begin{array}{l}\text { Tarpuplaučio limfmazgiu } \\
\text { metastazès }\end{array}$ & $\begin{array}{l}2011 \mathrm{~m} . \\
\text { lapkritis }\end{array}$ & - & 50 Gy, 25 fr & $\begin{array}{l}\text { Metastazių } \\
\text { redukcija; } \\
\text { stabili liga }\end{array}$ \\
\hline $\begin{array}{l}\text { Juosmens srities minkštujų } \\
\text { audinių metastazės (m. } \\
\text { obliqus abdominis major et } \\
\text { minor) }\end{array}$ & $\begin{array}{l}2012 \mathrm{~m} \text {. } \\
\text { rugpjūtis }\end{array}$ & + & $\begin{array}{l}\text { Pooperacinė } \\
\text { ST (R1) } \\
56 \text { Gy, } 28 \text { fr }\end{array}$ & Pilnas atsakas \\
\hline $\begin{array}{l}\text { Nugaros smegenų kanalo } \\
\text { metastazès } \\
\quad(\text { VL2-VL3) }\end{array}$ & $\begin{array}{l}2013 \mathrm{~m} . \\
\text { lapkritis }\end{array}$ & + & $\begin{array}{l}\text { Pooperacinė } \\
\text { ST (R1) } \\
45 \text { Gy, } 25 \mathrm{fr}\end{array}$ & $\begin{array}{l}\text { Stabili liga } \\
(14 \text { mèn.) }\end{array}$ \\
\hline $\begin{array}{l}\text { Nugaros smegenų kana- } \\
\text { lo metastazès su stuburo } \\
\text { slankstelių pažeidimu } \\
\text { (VL2-VL4) }\end{array}$ & $\begin{array}{c}2015 \mathrm{~m} . \\
\text { kovas }\end{array}$ & + & $\begin{array}{l}\text { Pooperacinė } \\
\text { (R1) } \\
\text { pakartotina } \\
\text { ST } \\
30,6 \mathrm{~Gy}, \\
17 \mathrm{fr}\end{array}$ & $\begin{array}{l}\text { Mielopatijos } \\
\text { simptomų } \\
\text { dalinè regre- } \\
\text { sija, skausmi- } \\
\text { nio sindromo } \\
\text { kontrolè iki } \\
2015 \text { m. rug- } \\
\text { pjūčio mèn. }\end{array}$ \\
\hline
\end{tabular}

tyvia chemoterapija. Spindulinio gydymo etapai aprašyti 1 lentelejje. Bendra paciento aktyvaus stebejjimo ir gydymo laikotarpio trukmè nuo kreipimosi ị mūsų centrą - 43 mẻn.

\section{Aptarimas}

Svarbiausias chondrosarkomų kombinuoto gydymo vaidmuo tenka operaciniam gydymo metodui. Operuojant sarkomas siekiama maksimalaus radikalumo, nes rezidualinis navikas sąlygoja sarkomos recidyvavimą. Rekomenduojama chirurgiškai šalinti ir naviko metastazes. Chemoterapijos efektyvumas gydant šiuos navikus nèra didelis, geresnis atsakas nustatomas mezenchiminès blogai diferencijuotos chondrosarkomos atveju. Nors radiobiologiškai chondrosarcoma dèl lètos proliferacijos ir mažo besidalijančių navikinių ląstelių skaičiaus priskiriama prie radiorezistentiškų navikų, spindulinès terapijos vaidmuo svarbus, kai pirminé chondrosarkoma ar jos metastazès yra neoperabilios arba naviko rezekcija neradikali. Taip pat tais atvejais, kai išsenka sisteminès chemoterapijos rezervai. Siekiama realizuoti $>60$ Gy spindulinès terapijos dozę. Tačiau spinalinių ar kaukolès pamato chondrosarkomų atveju, kai šalia yra neurologinès anatominès struktūros - nugaros smegenys, dozę tenka redukuoti atsižvelgiant $i$ aplinkinių audinių tolerancijos ribas. Jei navikas nerezektabilus, rekomenduojamas savarankiškas radikalus arba paliatyvus spindulinis gydymas (1). Siekiant eskaluoti spindulinès terapijos dozę, chondrogeniniams navikams gydyti pasitelkiama protonų terapija, moduliuoto intensyvumo ar volumetriškai moduliuojamo intensyvumo spindulinè terapija. Eskaluojant dozę iki biologiškai ekvivalentinès $70 \mathrm{~Gy}$, lokalios kontrolès rezultatai siekia $85-100 \%$ švitinant kombinuota fotonų-protonų terapija arba vien tik protonų terapija su minimalia $<10 \%$ vèlyvujų komplikacijų rizika (III ${ }^{\circ}$ pagal RTOG) $(2,3)$. Mažiau naudos pasiekiama skiriant konvencinę spindulinę terapiją paliatyviu tikslu, tačiau mokslo tyrimų rezultatai parodé, kad mezenchiminès chondrosarkomos yra jautresnès spinduliniam gydymui. Pristatytas klinikinis atvejis pademonstravo, kad, išnaudojus visas sisteminès chemoterapijos galimybes, paliatyvi spindulinè terapija kombinuojama su operaciniu gydymo metodu gali sustabdyti ligos progresavimą ar sékmingai kontroliuoti ligos simptomus. Pacientas mūsų centre buvo švitintas keturis kartus. Tarpuplaučio ir juosmens srities metastazès po operacinio ir spindulinio gydymo neprogresavo, lumbalinès srities stuburo kanalo metastazès po dviejų operacijų ir spindulinio gydymo recidyvavo, buvo nuspręsta skirti pakartotiną spindulinị gydymą i stuburo liemens srities (VL2-4) metastazes panaudojant naują volumetriškai moduliuojamo intensyvumo spindulinès terapijos metodą. Šio metodo pagalba, saugiai blokavus kritines nugaros smegenų struktūras, pakartotinai realizuota paliatyvi spindulinès terapijos dozè, gautas geras nuskausminamasis efektas, dalinè neurologinių simptomų regresija. Toliau vykdant aktyvią stebėseną vèlyvujų sunkaus laipsnio spindulinių reakcijų nepasireiškè. Paciento gydymo ir aktyvaus stebèjimo mūsų centre laikotarpis tęsiasi 43 mèn. Išplitusi IV stadijos mezenchiminè chondrosarkoma buvo diagnozuota prieš 79 mèn.

\section{Išvados}

1. Klinikinè patirtis parodè, kad spindulinè terapija efektyvi gydant mezenchimines chondrosarkomas.

2. Paliatyvi spinduline terapija gali duoti geru lokalios kontrolès rezultatų kombinuojant chondrosarkomos metastazių chirurgini gydymą su spinduline terapija.

\section{Literatūra}

1. Gelderbrom H, Hogendoorn PCV, Dijkstra SD, Rijswijk CS, Krol AD. et al. The Clinical Approach Towards Chondrosarcoma. The Oncologist 2008.13:320-329. 
2. Noel G, Habrand JL, Jaufret E. et al. Radiation therapy for chordoma and chondrosarcoma of the skull base and the cervical spine. Prognostic factors and patterns of failure. Strahlenther Oncol 2003; 179:241-248. http://dx.doi.org/10.1007/s00066-003-1065-5

3. Weber DC, Rutz HP, Pedroni ES. et al. Res proton radiation therapy for chordoma and chondrosarcoma of the skull base: The Paul Scherrer Institut experience. Int J Radiat Oncol Biol Phys 2005;63:401-409. http://dx.doi.org/10.1016/j.ijrobp.2005.02.023

4. Kawaguchi S, Weiss I, Lin PP, Huh WW, Lewis VO. Radiation therapy is associated with fewer recurrences in mesenchymal chondrosarcoma. Clin Orthop Relat Res 2014 Mar;472(3):85664.

http://dx.doi.org/10.1007/s11999-013-3064-x

\section{RADIOSENSITIVITY OF CHONDROSARCOMAS: A CASE OF SPINAL CHONDROSARCOMA}

\section{A. Plieskienè}

Key words: chondrosarcoma, radiosensitivity, radiotherapy. Summary

Chondrosarcomas are slow-growing, malignant mesenchymal tumours characterized by the formation of cartilage by the tumour cells, high-grade malignant lesions with aggressive local behavior and metastatic potential.

As chondrosarcomas grow slowly, with a relatively low fraction of dividing cells, and radiotherapy acts at dividing cells, chondrogenic tumors are considered relatively radiotherapy resistant.

Radiotherapy can be considered in two situations: after incomplete resection, aiming at maximal local control (curative), and in situations where resection is not feasible or would cause unacceptable morbidity (palliative). For curative intentions, doses $>60$ Gy are required to achieve local control. However, application of this dose with conventional high-energy photon RT is often impossible in the vicinity of critical (neurological) structures, especially in chondrosarcomas arising in the skeleton. In this situation, postoperative RT is often indicated because these tumors or metastases are less accessible for radical resection.

The clinical case of spinal chondrosarcoma demonstrates that disseminated not resectable chondrosarcomas, especially mesenchymal, which do not respond to the chemotherapy, may be considered for palliative radiotherapy with good local control results.

Correspondence to: aista.plieskiene@gmail.com

Gauta 2015-09-07 